\title{
กเแแแแแแแแแแแแแแแแกแ 論 文 軸受鋼の寿命に及ぼす冷間圧延と高温加熱

\author{
Effect of Cold Working and High Temperature Treatment of High \\ Carbon Chromium Bearing Steel on Its Rolling Contact Fatigue Life
}

\author{
Kazuichi Tsubota, Kimio Ohnishi, Takashi Sakajo, and Akiyoshi Ishinara
}

Synopsis :

High-carbon chromium bearing steel tubes rolled in the cold pilger mill were tested in the thrust type rolling contact fatigue testing machine. Their fatigue lives were evaluated as influenced by cold rolling and also by spheroidization at high temperature heat treatment of sulfides elongated during cold rolling. Life of cold rolled tubes with a regular $70 \%$ of reduction in area extended more than three times as long as that of hollows and the same cold rolled ones endured over six times more than hollows when heat treated as high temperatures subsequent to cold rolling. It was revealed that nonmetallic inclusions finely dispersed by cold rolling and sulfides spheroidized by high temperature treatment as well contributed to a remarkable improvement in fatigue life of high-carbon chromium bearing steel.

\section{1. 緒言}

ころがり軸受の寿命（はく離発生までの総応力くり返 し数）が改善されると軸受の信頼性が向上し，それを使 用する機械の性能向上もしくは軸受自体の小型軽量化が 可能となる. 従来から軸受の寿命の向上に関しては多く の研究が行われてきた. 特に鋼質面に関しては溶鋼の脱 ガス処理などによる鋼中の酸化物系介在物の減少が顕 著な寿命改善効果をもたらすことが明らかにされてい る1) 3). このことは酸化物系介在物の周辺に発生する応 力集中4) がはく離の発生に大きな影響を及ぼすことを意 味している.

一方鋼中での非金属介在物の量が同じであつてもそれ らが微細に分散しておれば個々の介在物粒子の寸法は小 さいはずである、したがつてそれによる局部的な応力集 中の及ぶ範囲が狭くなり ${ }^{4)}$, 結局非金属介在物の微細化 は寿命の向上をもたらすはずである.

最近小型・量産軸受（ 工の能率向上を主目的として冷間ピルガー圧延機5)によ る冷間圧延鋼管から製造されることが多い。このような 鋼管では非金属介在物の総量自体は冷間圧延の前後で変 化せず，冷間圧延によつて必然的におこると考えられる 非金属介在物の形状变化一酸化物系介在物の破砕による 微細化と硫化物系介在物の延伸一が寿命に何らかの影響 を及ぼすであろう。
そこで本研究では冷間ピルガー在延による非金属介在 物の形状変化による寿命への影響を調査した。 また， ス ラスト型ころがり疲れ試験機6) (以下スラスト試験機, その試験片をスラスト試験片）による寿命試験用のスラ スト試験片作成時の熱処理によつて冷間圧延で長く伸び た硫化物系介在物が著しく球状化することが判明したの で寿命に及ぼすその効果についても調査した.

な㧧化物系介在物が高温加熱によつて球状化すると いうことについての報告7は見られるが，ころがり寿命 とそれとの関連を述べた報告はまだないよらである.

\section{2. 供試材および実験方法}

\section{$2 \cdot 1$ 供試材}

本実験では供試材として $60 \mathrm{t}$ 電気炉で溶製し脱ガス 処理を行つた SUJ 2 を用いた. その化学成分を Table 1 に示す.

本実験では酸素含有量と $\mathrm{S}$ 含有量の異なるヒートを選 定し, 酸化物系介在物と硫化物系介在物の総量と, 冷間 圧延によるそれらの形状変化の寿命に及ぽす影響につい ても調查した.

\section{$2 \cdot 2$ ころがり疲れ試験方法}

本実験ではスラスト試験機によつてころがり疲れ試験 を行つた。試験条件を以下に示す．なおこの試験機で得 られる寿命は実体軸受のそれと定性的によく一致すると いわれている8).

昭和 55 年 10 月本会講演大会にて発表 昭和 58 年 9 月 6 日受付 (Received Sep. 6, 1983)

* 山陽特殊製鋼 (株) 技術研究所 (Technical Research Laboratories, Sanyo Special Steel Co., Ltd., 3007 Aza-Ichimonji Nakashima Shikama-ku 672)

*2 山陽特殊製鋼 (株) (Sanyo Special Steel Co., Ltd.) 
Table 1. Chemical composition of high carbon chromium bearing steels tested (wt \%).

\begin{tabular}{cccccccccccc}
\hline heat & $\mathrm{C}$ & $\mathrm{Si}$ & $\mathrm{Mn}$ & $\mathrm{P}$ & $\mathrm{S}$ & $\mathrm{Ni}$ & $\mathrm{Cu}$ & $\mathrm{Mo}$ & $\mathrm{Cu}$ \\
\hline A & 0.98 & 0.23 & 0.29 & 0.011 & 0.013 & 0.05 & 1.31 & 0.02 & 0.06 & 0.0014 \\
B & 0.98 & 0.23 & 0.29 & 0.010 & 0.014 & 0.04 & 1.32 & 0.01 & 0.07 & 0.0014 \\
C & 1.02 & 0.22 & 0.28 & 0.007 & 0.012 & 0.03 & 1.32 & 0.01 & 0.06 & 0.0012 \\
D & 0.99 & 0.31 & 0.47 & 0.013 & 0.013 & 0.04 & 1.41 & 0.02 & 0.07 & 0.0010 \\
E & 0.98 & 0.25 & 0.37 & 0.016 & 0.002 & 0.03 & 1.39 & 0.01 & 0.02 & 0.0008 \\
F & 0.98 & 0.31 & 0.46 & 0.017 & 0.009 & 0.05 & 1.40 & 0.02 & 0.06 & 0.0006 \\
G & 1.00 & 0.27 & 0.41 & 0.012 & 0.013 & 0.04 & 1.33 & 0.02 & 0.05 \\
\hline
\end{tabular}

○最大ヘルッ圧縮応力 $\left(P_{\max }\right)$

$: 500 \mathrm{kgf} / \mathrm{mm}^{2}$

。応力くり返し速度

。潤滑油

。潤滑油温度

: 1800 c.p.m.

: $¥ 60$ スピンドル油

$: 30 \sim 31^{\circ} \mathrm{C}$

。試験片表面仕上げ $\left(H_{\max }\right)$

$: \sim 0.35 \mu \mathrm{m}$

。弾性流体潤滑油膜厚パラメータ: 約 0.7

(TAllian ${ }^{9}$. Cheng ${ }^{10)}$ の式による)

。スラスト試験片かたさ

: HRC $62 \sim 63$

\section{3 スラスト試験片作成方法}

供試材の冷間圧延には冷間ピルガー圧延機を用いた. その主要部を Fig. 1 と示す.

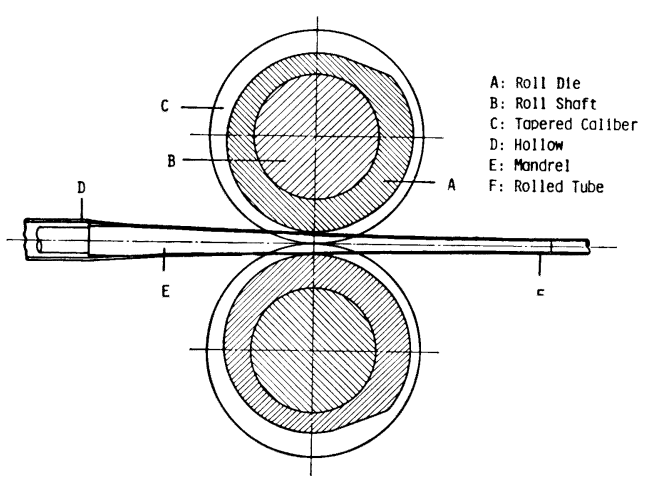

Fig. 1. Schematic view of cold pilger rolling.

冷間ピルガー圧延は鋼管の内径を決定するためのマン ドレルを素管の内面に挿入し，オーバル形状の穴型を有 する上下一対のロールが往復運動を行らことによつて外 径および肉厚を減少せしめることによつて行われる。 、 ンドレルは压延中一定の位置に固定されている。また口 一ルの往復ごとに素管を一定角度回転せしめ, 同時に素 管を前方へ送り，しだいに外径と肉厚とを減少せしめて 所定の寸法に仕上げる.したがつて 1 回の圧延で大きな 減面率 (SUJ 2 の場合通常最高 75\% 程度) がとれるた め, 同一減面率にするには加工途中で数回の焼なまし, 脱脂, 矯正を必要とする引き抜きより生産性が良い。

本実験では冷間ピルガー圧延用素管および冷間圧延管 から次の方法によつて厚さ約 $5 \mathrm{~mm}$ のスラスト試験片
を作成した。

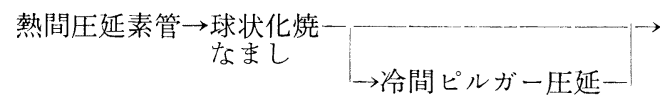

$\rightarrow$ 切断 $\rightarrow 650^{\circ} \mathrm{C}$ 平板加工 $(60 \mathrm{~mm} \times 60 \mathrm{~mm} \times 5 \mathrm{~mm}) \rightarrow$

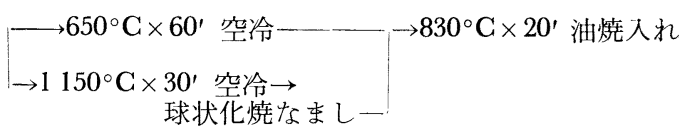

$\rightarrow 180^{\circ} \mathrm{C}$ 焼もどし $\rightarrow$ 研磨 $\rightarrow$ ススト試験

本実験では焼もどし時間の調整によつてスラスト試験 片のかたさを HRC 62〜63 とした。 また本実験では上 述の $650^{\circ} \mathrm{C} \times 60^{\prime}$ 空冷材と, $1150^{\circ} \mathrm{C} \times 30^{\prime}$ 空冷 $\rightarrow$ 球状化 焼なまし材とを $830^{\circ} \mathrm{C}$ で油焼入れし，さらに焼もどし をしたスラスト試験片について炭化物粒度, 残留オース テナイト量, および炭化物の面積率を調査した. その結 果後述するよらにいずれの場合も著しい差異が認められ なかつた。したがつて以下の寿命試験結果が上述のスラ スト試験片の製造履歴の差異の影響を受けていることは ないと判断した.

なおスラスト試験はすべて鋼管の外面について行つ た.また厚さ $5 \mathrm{~mm}$ のスラスト試験片が各減面率によ る冷間圧延管から採取できるよう素管の寸法㧍よび冷間 压延寸法を調整した。

\section{4 硫化物系介在物の球状化率の定義}

硫化物系介在物の球状化率の寿命に及ぼす影響を評価 するため, 硫化物系介在物の球状化率を次のように定義 した.

試片を 1000 倍で検鏡したとき，長さ $7 \mu \mathrm{m}$ 以上にわ たつて分離して断続的に球状化した硫化物系介在物が注 ぼ一直線上にならび, かつもともと 1 ケの硫化物系介在 物であつたと観察されるものを “球状化した硫化物”之 見なし, 単位検鏡面積内での硫化物系介在物 (長さ $7 \mu \mathrm{m}$ 以上のもの)の総個数に占める “球状化硫化物系介在物” の個数を球状化率とした.

ここで $7 \mu \mathrm{m}$ を限界長さとしたのは, これ以下の長さ の硫化物系介在物は球状化しても 2 ケ以上に分離するこ とが少ないのと, あまり短い場合真に球状化したのかど らか判断しにくいといら実験手法上の理由による. 


\section{3. 実 験 結 果}

\section{1 冷間圧延による非金属介在物の形状変化}

鋼中の酸化物系介在物はその応力集中作用によつて寿 命を著しく低下させる1) 3). 一方硫化物系介在物の場合 はとれが酸化物系介在物を包含して寿命を改善するとい ら説11)12) と, 単独で寿命を低下させるというもの ${ }^{13)}$ と, さらに汇とんど影響しないといらもの1)などがある.

またこれら非金属介在物の寿命への影響は, その総量 とともに形態あるいは個々の寸法によつても異なると考 えられ，本実験のように総量が同じであつても冷間圧延 により非金属介在物が微細化される場合には寿命が改善 される可能性がある.

一方，冷間压延した鋼管を $650^{\circ} \mathrm{C}$ で平板に加工し， $650^{\circ} \mathrm{C}$ で歪久取焼なましを行つた場合には硫化物系介
在物の形状はほとんど変化しないが，軸受鋼の通常の熱 間加工温度に近い $1150^{\circ} \mathrm{C}$ に加熱すると硫化物系介在 物が著しく球状化することが判明した.

そこで本実験では硫化物系介在物の球状化の寿命への 影響を調査するため, 高温加熱処理によつて硫化物系介 在物を球状化した場合についても寿命試験を行つた.

Photo. 1 は減面率 $0 \%$ (素管) と, 約 70\% の冷間圧 延管を $650^{\circ} \mathrm{C}$ で平板に加工した場合の硫化物系介在物 のミクロ組織の一例である。また Photo. 2 減面率約 $70 \%$ の冷間圧延鋼管に括ける，高温加熱処理による硫 化物系介在物の形状变化を示したものである。これらに よると泠間圧延によつて硫化物系介在物がやや薄くなる ことと, 冷間圧延しない場合には高温加熱処理をしても 硫化物系介在物は汪之んど球状化しないが，冷間圧延を すると高温加熱処理によつて著しく球状化することがわ

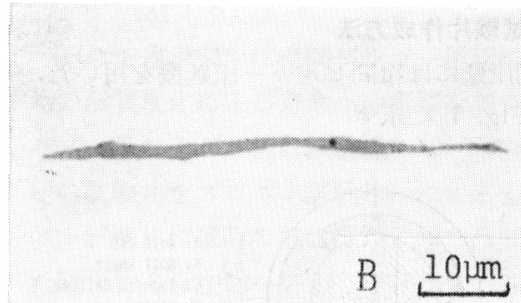

A : Cold rolling reduction of area $=0 \%$ (hollow)

$\mathrm{B}$ : Cold rolling reduction of area $=70 \%$ (Heat A flattened at $650^{\circ} \mathrm{C}$ )

Photo. 1. Microstructure of sulfide in high-carbon chromium bearing steel tubes.

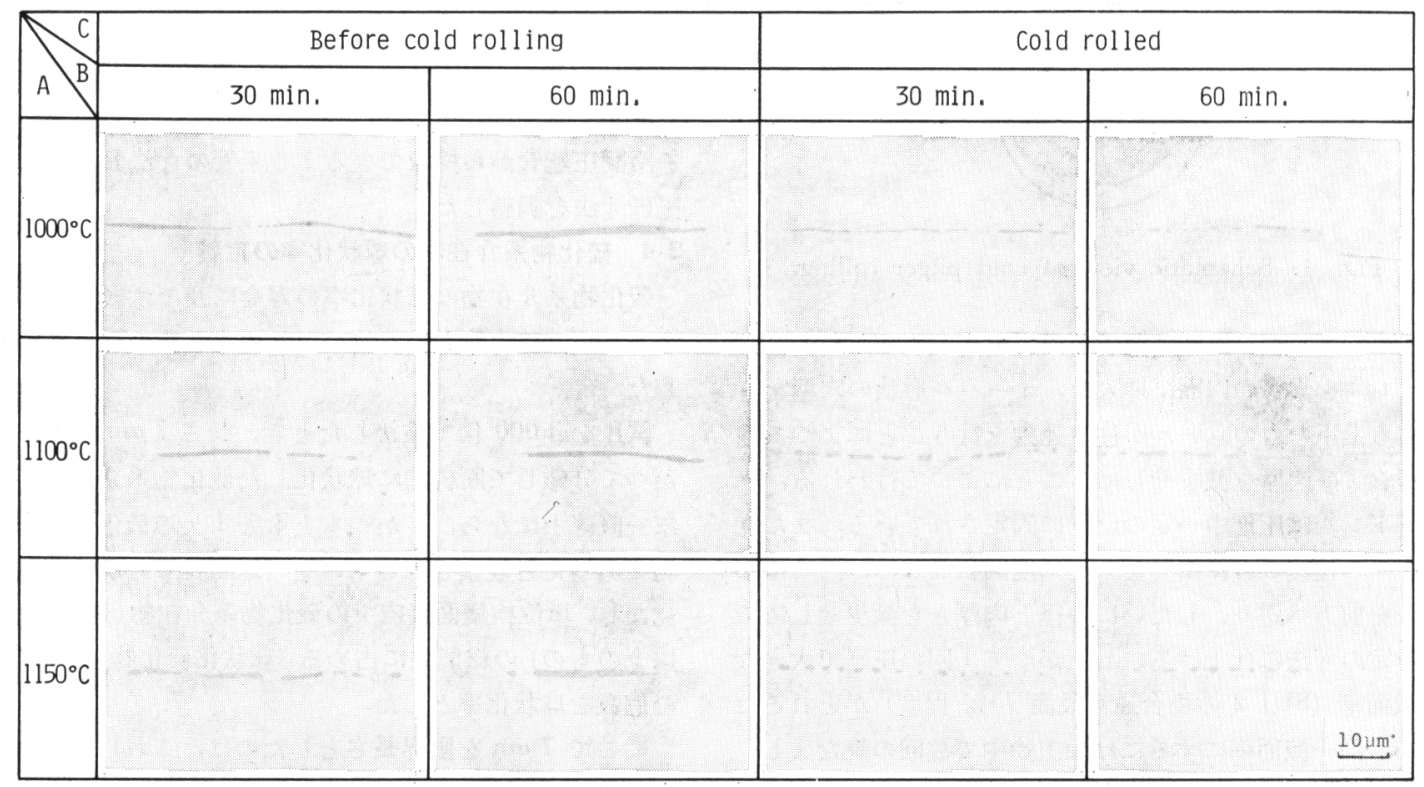

A : heating temperature, B : holding time, $\mathrm{C}$ : cold pilger rolling.

Photo. 2. Change of sulfide inclusion shape in heat A by high temperature treatment subsequent to $70 \%$ reduction of area. 
かる. 本実験ではこの結果から冷間压延管では $1150^{\circ} \mathrm{C}$ $\times 30^{\prime}$ 加熱で満足すべき球状化状態が得られるものと判 断し，以下の実験ではこの処理を用いた。

な和硫化物系介在物は Photo. 3 飞示寸ように酸化物 系介在物をしばしば包含している。 また Photo. 3-B か らもわかるように本実験ではこのよらな複合介在物が冷 間圧延により分離したよらな例は観察されなかつた。こ のような複合介在物では冷間圧延によつて主として外周 の硫化物系介在物が延伸し, その後の高温加熱処理によ つて球状化するが，はじめに包含されていた酸化物系介 在物はあまり変形せず，その外周を球状化した硫化物系 介在物が包含しているものが多く観察された.

また Photo. 4 に酸化物系介在物の泠間圧延に上る変 化を示す。このように酸化物系介在物は冷間圧延でかな り破砕され，1000 倍程度で検鏡しても乥の周辺にボイ ドは観察されなからた。㐬さ然のことであるが破砕さ れた酸化物系介在物は $1150^{\circ} \mathrm{C}$ の高温加熱処理をして も气の形状の変化は生じなかつた。

な牤本実験ではあらかじめいくつかの硫化物系介在物

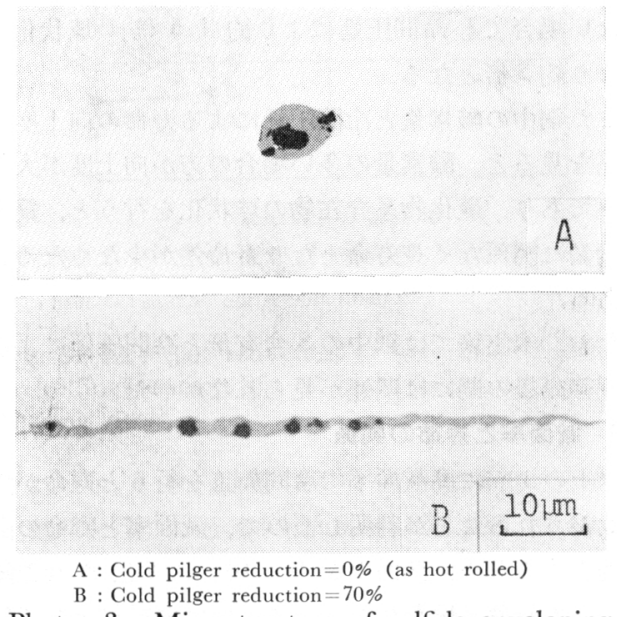

Photo. 3. Microstructure of sulfide enveloping oxides in high-carbon chromium bearing steel.
についてX線マイクロアナライザで組成を調査した。 そ の結果すべての硫化物系介在物は $\mathrm{MnS}$ であり, $\mathrm{CaS}$ は認められなからた。したがつて本実験に打ける供試材 中の硫化物系介在物はすべて MnS であると考えてよい であるら。

\section{$3 \cdot 2$ 寿命試験結果}

泠間圧延用素管之, 約 70\% の減面率で泠間圧延した 鋼管について, $650^{\circ} \mathrm{C}$ で平板に加工した後で $650^{\circ} \mathrm{C}$ で 焼なましをした場合と， $1150^{\circ} \mathrm{C}$ で加熱処理した場合と についてそれぞれ寿命試験を行つた。

寿命は鋼中の酸素量の増加とともに低下寸る傾向があ る.しかし本実験のように鋼中の非金属介在物の総量が 変化せず，単に冷間圧延によつてその形態のみが変化す る場合, 従来得られている寿命之酸素量の関係に関する 知見1) 3) と一致するかどらかは明らかでない。そこで本 実験では鋼材の横断面（T面）から採取したスラスト試 験片について得られている酸素量と寿命の関係と, ここ で得られた鋼管におけるそれとを比較した。

な持鋼材の T面について得た寿命と鋼管の表面の寿命 とが酸素量に関して同様の傾向を示すかどらかは不明で あるが，鋼管に特いても酸素量の増加は当然酸化物系介 在物量の増加をもたらし，寿命を低下させると考学られ る。

Table 2 にスラスト試験片の炭化物粒度, 残留オー ステナイト量, 拉よび残留炭化物面積率を示す。いずれ の数值も heat ごとに汪とんど差がなく，寿命試験結果 の評価に打いて冷間圧延以外のスラスト試験片製造履歴 の差異は無視できると考えられる.

寿命試験結果を Fig. 2 に示す。ここに示した寿命は すべて $\mathrm{L}_{10}$ 寿命 $(90 \%$ 残存確率寿命) である。これに よると冷間圧延を行わない鋼管の寿命之酸素量の関係 は，基本的には従来得られている Fig. 2 中に示した鋼 材の T面の寿命と酸素量の関係とほぼ同じであり，冷間 圧延を行うとこの関係から同一酸素量でも長寿命側へず れることがわかる.
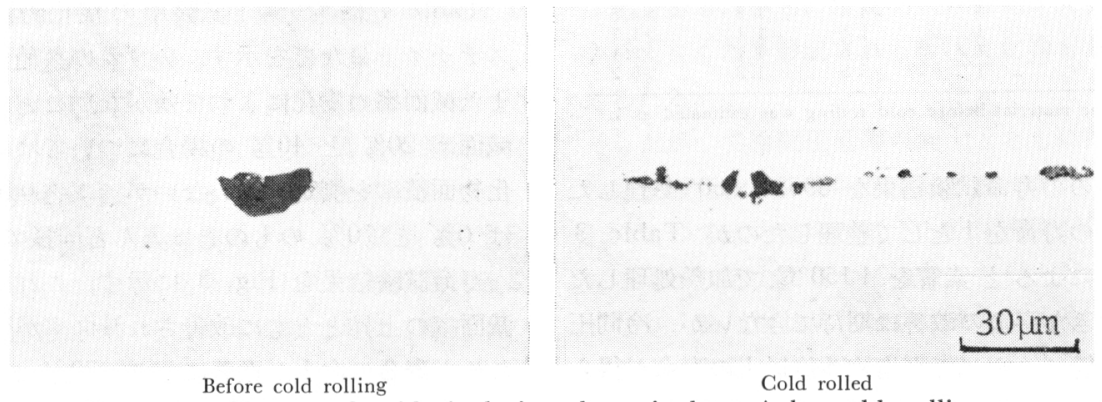

Photo. 4. Change of oxide inclusion shape in heat A by cold rolling. 
Table 2. Retained austenite, carbide size and carbide area of rolling contact fatigue testing specimens used to investigate the effect of heating temperature on life.

\begin{tabular}{|c|c|c|c|c|c|c|c|c|c|c|c|c|}
\hline \multirow{3}{*}{$\begin{array}{l}{[1]} \\
{[2]} \\
{[3]}\end{array}$} & \multicolumn{6}{|c|}{$650^{\circ} \mathrm{C}$} & \multicolumn{6}{|c|}{$1150^{\circ} \mathrm{C}$} \\
\hline & \multicolumn{3}{|c|}{ Before cold rolling } & \multicolumn{3}{|c|}{ Cold rolled } & \multicolumn{3}{|c|}{ Before cold rolling } & \multicolumn{3}{|c|}{ Cold rolled } \\
\hline & $r_{\mathrm{R}} \%$ & C.S. $\mu \mathrm{m}$ & C. A. $\%$ & $r_{R} \%$ & C.S. $\mu \mathrm{m}$ & C. A. $\%$ & $\gamma_{\mathrm{R}} \%$ & C.S. $\mu \mathrm{m}$ & C. A. $\%$ & $\gamma_{\mathbf{R}} \%$ & C.S. $\mu \mathrm{m}$ & C. A. $\%$ \\
\hline A & 8 & 0.43 & 8.6 & 7 & 0.41 & 8. 3 & 8 & 0.42 & 8.5 & 7 & 0.43 & 8.3 \\
\hline B & 7 & 0.43 & 8.4 & 9 & 0.42 & 8. 4 & 8 & 0.42 & 8. 4 & 10 & 0.44 & 8.3 \\
\hline $\mathrm{C}$ & 8 & 0.41 & 8.7 & 8 & 0.44 & 8.5 & 7 & 0.43 & 8. 6 & 9 & 0.43 & 8.5 \\
\hline D & 8 & 0.42 & 8. 5 & 9 & 0.43 & 8. 4 & 7 & 0.44 & 8.3 & 8 & 0.44 & 8.4 \\
\hline E & $\begin{array}{l}0 \\
7\end{array}$ & 0.44 & $\begin{array}{l}0.5 \\
8.4\end{array}$ & 8 & 0.43 & $\begin{array}{l}0.4 \\
8.4\end{array}$ & 10 & $\begin{array}{l}0.44 \\
0.43\end{array}$ & 8.3 & 7 & 0.42 & 8.5 \\
\hline $\mathrm{F}$ & 10 & 0.43 & 8. 4 & 7 & 0.42 & $\begin{array}{l}8.3 \\
8.3\end{array}$ & 8 & 0.44 & $\begin{array}{l}8.5 \\
8.5\end{array}$ & 8 & 0.42 & $\begin{array}{l}.0 \\
8.5\end{array}$ \\
\hline $\mathrm{G}$ & 8 & 0.45 & 8.8 & 10 & 0.44 & 8.8 & 8 & 0.43 & 8. 7 & 9 & 0.44 & 8. 6 \\
\hline
\end{tabular}

[1]: Heating temperature for flattening of tubes.

[2]: Condition of tubes. $[3]: \gamma_{\mathrm{R}}$ : retained austenite, C.S. : carbide size (Mean value of carbide segments intercepted by linear analysis), C. A.: carbide area.
[4]: Heat No.

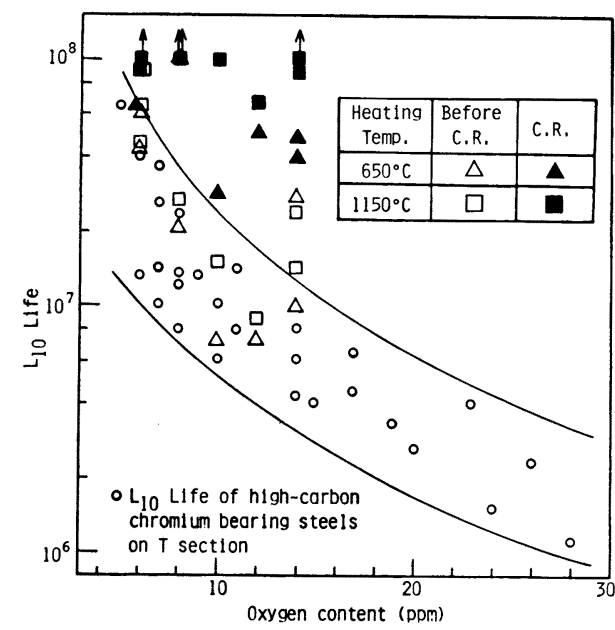

C.R. : cold rolling.

Heating temperature : Heating Temperature for flattening of tube.

Fig. 2. Effect of oxygen content on rolling contact life of high-carbon chromium bearing steels.

Table 3. Change in life of cold pilger rolled high carbon chromium bearing steels tubes*.

\begin{tabular}{cccccr}
\hline heat & $\begin{array}{c}\text { Oxygen } \\
\text { content } \\
\text { ppm) }\end{array}$ & $\begin{array}{c}\text { heated at } \\
\begin{array}{c}\text { Before cold } \\
\text { rolling }\end{array}\end{array}$ & $\begin{array}{c}\text { Cold } \\
\text { rolled }\end{array}$ & $\begin{array}{c}\text { heated at } \\
\begin{array}{c}\text { Before cold } \\
\text { rolling }\end{array}\end{array}$ & $\begin{array}{c}\text { Cold } \\
\text { rolled }\end{array}$ \\
\hline A & 14 & 1 & 4.0 & 1.4 & 8.8 \\
B & 14 & 1 & 1.7 & 0.9 & $>3.6$ \\
C & 12 & 1 & 6.9 & 1.2 & 9.0 \\
D & 10 & 1 & 4.0 & 2.1 & 13.6 \\
E & 8 & 1 & $>4.8$ & 1.3 & $>4.8$ \\
F & 6 & 1 & 1.5 & 1.1 & $>1.7$ \\
G & 6 & 1 & 1.5 & 1.1 & 2.1 \\
mean & - & 1 & $>3.5$ & 1.3 & $>6.2$ \\
\hline
\end{tabular}

* Life of tube material before cold rolling was estimated as 1 .

またおのおのの寿命試験結果を $650^{\circ} \mathrm{C} \times 60^{\prime}$ 処理した 冷間圧延素管の寿命を 1 として整理したのが Table 3 である.これによると素管を $1150^{\circ} \mathrm{C}$ で加熱処理した 場合あまり大きな寿命の改善は期待できないが, 冷間圧 延をすると素管にくらべて平均約 3 倍以上の寿命が得ら れており，さらにこれを $1150^{\circ} \mathrm{C} て ゙$ 加熱処理すると素
管の平均約 6 倍以上の寿命が得られることがわかる。な おこれらの数值については，害験時間の関係で有限の $\mathrm{L}_{10}$ 寿命が求められなかつたものがあるため铰密な意味 での寿命の改善度は求められないので, ここでは“〜倍 以上”といら表現を用いた.

また冷間圧延鋼管について硫化物系介在物の球状化処 理の有無について寿命を比較すると, 球状化によつて約 2 倍以上の寿命の改善が認められる.

本実験の範囲で寿命の改善度を直接比較すると, 最も 少ない場合でも冷間圧延により約 1.5 倍, 球状化処理 により約 2 倍となる.

また鋼中の酸素量と冷間圧延による寿命の向上度との 関係を見ると, 酸素量の多い場合の方が向上度が大きい ようであり, 硫化物系介在物の球状化を行うと, 鋼中の 酸素量に関係なく長寿命となり寿命差が少なくなるよら である。

なお，本実験では鋼中の $\mathrm{S}$ 含有量と冷間圧延による寿 命改善効果の間には関連が見られなかつた。

\section{3 隇面率と寿命の関係}

以上のように高減面率で泠間加工を行うと寿命が大幅 に改善されることが判明したので, 減面率と寿命の関係 を調査するため, 減面率を 0〜70\% に変化させた鋼管 について寿命試験を行つた。ここでは供試材として酸素 量の上限と下限のものを選んだ.

Table 4 にスラスト試験片の炭化物粒度, 残留才一 ステナイト量などを示す. いずれの数值も heatごとに, また減面率の変化によつて差がないことがわかる。なお 減面率 $20 \%$ と $40 \%$ の場合については炭化物粒度と炭 化物面積率を測定していないが， ミクロ組織観察によれ ば 0\%と70\%のものと汪とんど同様であつた.

寿命試験結果を Fig. 3 に示す. これによると寿命は 減面率の上昇とともに改善され減面率が約 $30 \%$ 以上に なると寿命の向上が顕著になり，70\%ではほぼ飽和し ているよらである。 
Table 4. Retained austenite, carbide size and carbide area of rolling contact fatigue test specimens used to investigate the effect of reduction of area on life.

\begin{tabular}{|c|c|c|c|c|c|c|c|c|c|}
\hline \multirow[t]{3}{*}{ heat } & \multirow{3}{*}{$\frac{\begin{array}{c}\text { Heating } \\
\text { tempera- } \\
\text { ture*1 }\end{array}}{\left({ }^{\circ} \mathrm{C}\right)}$} & \multirow{2}{*}{\multicolumn{4}{|c|}{$\frac{\begin{array}{c}\text { Retained } \\
\text { austenite }(\%)\end{array}}{\text { Reduction (\%) }}$}} & \multirow{2}{*}{\multicolumn{2}{|c|}{$\frac{\begin{array}{c}\text { Carbide size } \\
(\mu \mathrm{m})^{* 2}\end{array}}{\text { Reduction }(\%)}$}} & \multirow{2}{*}{\multicolumn{2}{|c|}{$\frac{\begin{array}{c}\text { Carbide area } \\
(\%)\end{array}}{\text { Reduction }(\%)}$}} \\
\hline & & & & & & & & & \\
\hline & & 0 & 20 & 40 & 70 & 0 & 70 & 0 & 70 \\
\hline A & 1150 & 9 & 8 & 8 & 7 & 0.42 & 0.44 & 0.44 & 0.42 \\
\hline $\mathrm{A}$ & 650 & 8 & 8 & 9 & 7 & 0.43 & 0.44 & 0.42 & 0.45 \\
\hline $\mathrm{G}$ & 1150 & 10 & 8 & 7 & 9 & 0.44 & 0.43 & 0.43 & 0.44 \\
\hline G & 650 & 8 & 7 & 8 & 8 & 0.42 & 0.43 & 0.44 & 0.43 \\
\hline
\end{tabular}

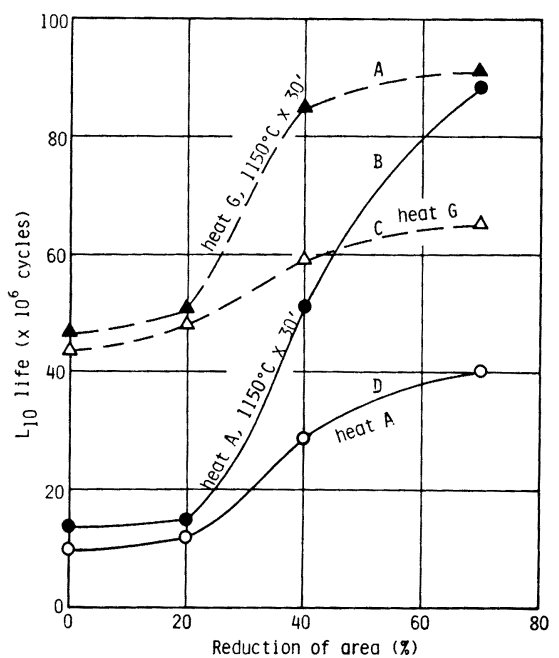

A : heat $\mathrm{G}$ : spheroidization of sulfide at $1150^{\circ} \mathrm{C} \times 30^{\prime}$.

$\mathrm{B}$ : heat $\mathrm{A}$ :

C : heat $\mathrm{G}$ : sulfides not spheroidized.

$\mathrm{D}$ : heat $\mathrm{A}$ :

Fig. 3. Effect of reduction of area in cold rolling on rolling contact life of high-carbon chromium bearing steels.

また Fig. 4 は $1150^{\circ} \mathrm{C} \times 30^{\prime}$ の硫化物系介在物の球 状化処理を行つた場合の減面率と球状化率の関係を示し たものである。

Fig. 3 と Fig. 4 を比較すると寿命の向上度と硫化 系物介在物の球状化率の変化とは定性的によく一致した 傾向を示しており, 硫化物系介在物の球状化が寿命を著 しく改善することがわかる.

な打軸受鋼管の実生産に和ける減面率は通常 60〜75 \% 程度であるから，実際には飽和した寿命改善度を有 する鋼管が市場に流通しているものと考えられる。

本実験と同一の条件で軸受鋼のスラスト試験を行ら と, はく離の直下に板状炭化物がしばしば観察されるこ とはすでに報告した ${ }^{14)}$ 。そこで本実験でもはく離直下の 板状炭化物の発生率を調査したところ，はく離の $81 \%$ （板状炭化物をともならはく離と総はく離数の比）に板

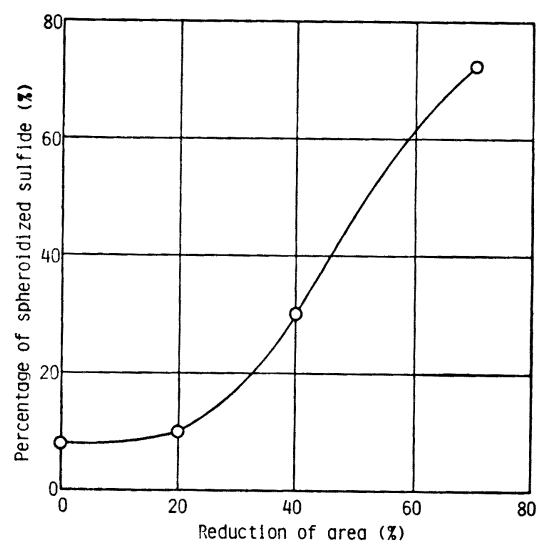

Fig. 4. Effect of reduction of area on percentage of spheroidized sulfides in heat A heated at 1150 ${ }^{\circ} \mathrm{C}$ for $30 \mathrm{~min}$. followed by air cooling.

状炭化物が観察された。

\section{4. 考察}

以上の結果から冷間圧延によつて軸受鋼の寿命がかな り改善されるとともに, さらに高温加熱処理を行らと寿 命が顕著に向上することが判明した。

焼入・焼もどしによつて HRC 62〜63 のかたさを有 する軸受鋼中ではころがり応力によつて基地中の $\mathrm{C}$ と が拡散し，拡散した $\mathrm{C}$ との量が多い場合は板状炭化物 を形成し，それらが少ない場合には Cottrell 雾井気を 形成していずれの場合も転動面下にき裂を生じてはく離 に到ることはすでに報告した14)15).

本実験の場合もこれと同様の現象が転動面下で起こつ ているはずであり, 前述のように微小な板状炭化物がは く離周辺に約 $81 \%$ 生成していることはとれを裏づけて いる.

一方板状炭化物はすでに報告したように酸化物系介在 物間の応力集中域に生成する16)。 またこのような領域で は $\mathrm{C}$ とがころがり応力によつて拡散 ${ }^{15)} し$ 富化している はずである.さらに酸化物系介在物が大きいほど応力集 中が大きくなり形成される板状炭化物も大きくなると考 えられる。

したがつて冷間圧延率の向上とともに寿命が问上する のは，酸化物系介在物が冷間圧延によつて破砕され，そ れによつて応力集中が低下し転位密度が相対的に低下し てころがり応力によつて拡散した $\mathrm{C} と \mathrm{~N}$ が捕捉されにく くなり，結局板状炭化物が生成しにくくなるか，あるい はミクロき裂が生成しにくくなるためであるう。

一方本実験では冷間圧延のほかに高温加熱処理による 
硫化物系介在物の球状化によつて顕著な寿命の向上が得 られることが判明した。

硫化物系介在物の熱膨脹係数は軸受鋼の基地のそれよ り大きいため，その周辺に圧縮の残留応力を生じさせ る.このため硫化物系介在物が酸化物系介在物を包含寸 るとその引張の残留応力を減じることになり，寿命が改 善さ机るといわ机ている17).

しかし一方で硫化物系介在物は浸岑鋼の问転曲げ疲れ において Fish eye の生成源となる ${ }^{18)}$ 。このように硫化 物系介在物は高硬度鋼中では応力集中源としての作用を 有している。また硫化物系介在物はその形態，大きさ， 転動面での位置によつては寿命に悪影響するともいわれ ている19)

こ机らの結果から考兵る之硫化物系介在物は，鋼中の 酸素量が多く酸化物系介在物が多い場合にはそ机を包含 して㤎力集中を低下させ寿命を改善するが，酸化物系介 在物が少ない場合は単独のものが増加してかえつて寿命 を低下させると考えるべきであるう。

本実験では酸化物系介在物を硫化物系介在物が包含し ている場合，冷間压延によつてそれらが分離したものは 観察されなかつた。したがつて，冷間庄延によつて酸化 物系介在物を硫化物系介在物が包含してその结力集中を 低下させる作用は消失しない。このことから冷間圧延後 長く延伸した硫化物を球状化させることによる寿命の向 上は結局硫化物系介在物の応力集中がその球状化によつ て低下したためであると考えるべきであるう。

一方上述したようにスラスト試験ではころがり忘力に よつて $\mathrm{C} と \mathrm{~N}$ が拡散し転動面下に板状炭化物を形成する か，あるいは $\mathrm{C} 之 \mathrm{~N}$ の富化域が形成されてそれらからき 裂が生じてはく離に到るわけであるが，硫化物系介在物 を球状化することによつて寿命が著しく改善されること から考光ると，硫化物系介在物はそ机単独の応力集中 か，あるい酸化物系介在物之の相互作用により $\mathrm{C}$ 之 $\mathrm{N}$ の富化域の形成を促進するか，あるいは板状炭化物の生 成等を促進する作用を有していると考觉られる。

したがつて軸受鋼中の $\mathrm{S}$ 含有量は切削性を考慮すると あまり少量にすることは問題があるが，鋼中の酸化物系 介在物を包含するに必要な量にとどああまり多量に添加 することは適当でない。

\section{5. 結}

\section{論}

寿命に及ぼす冷閒历:延およびそれにつづく高温加熱処
理の影響について調査し次の結果が得られた。

（1）軸受鋼を約 70\% の減面率で泠間ピルガー圧延 を行うと压延前の素管の寿命より平均約 3 倍以上寿命が 向上することが明らかとなつた。これには冷閒压延によ る酸化物系介在物の破䂶之硫化物系介在物の延伸とが寄 与していると思われる。

（2）冷間ピルガー圧伸後さらに高温加熱処理を行な う之硫化物系介在物が球状化し, 寿命が原素管の平均約 6 倍以上になることが水かつた。 そのことから硫化物系 介在物の球状化が寿命を著しく问上させることがわか る.

（3）硫化物系介在物の球状化による寿命の改善度 は，その球状化率の向上度之定性的に一致する。

本研究の遂行に当たり多大の御指導と御鞭撻をいただ いた当社代表取締役副社長上杉年一博士士，同専務取蟐役 小柳 明博士，抢よび供試材の製造ならびに寿命試験等 について御協力いただいたすくに厚く御礼申しはげま す.

\section{交献}

1) L. O. Uhrus: "Clean Steel", Iron Steel Inst. Spec. Rep., No. 77 (1963), p. 104

2 ) 結城 晋, 梶川和男, 山口 旻：鉄と鋼，51 (1965), p. 2071

3 ) 高田浩年：潤滑，14 (1969)，p. 485

4) D. Brooksbank and $K . W$. Andrews: JISI, 207 (1969), p. 474

5 ) F. W. Neumann and E. Siebel: Stahl Eisen, 74 (1954), p. 133

6 ) 上野 学, 中島宏興, 池田定雄：鉄と鋼，46 (1960), p. 344

7) 西田 稔，加藤俊之，田中哲夫：鉄と鋼，67 (1981), p. 1533

8 ）古村恭三郎, 平川 清: NSK Bearing Journal, No. 638 (1979), p. 1

9 ) T. E. Tallian: ASLE Trans., 10 (1967), p. 418

10) H. S. Cheng: Trans. ASME, J. of Lub. Tech., 92 (1970), p. 155

11) C. $M$. Lyne and $A$. Kasak: Trans. ASM, 61 (1968), p. 10

12) S. ENEKES: JISI, 210 (1972), p. 83

13）斎藤 誠, 関谷重信：電気製鋼，46(1975), p. 147

14）坪田一一：鉄と鋼，68（1982)，p. 1046

15）坪田一一: 鉄と鋼, 69 (1983), p. 853

16）坪田一一：鉄と鋼，68 (1982), p. 2037

17) $D$. Brooksbank and $K . W$. Andrews: JISI, 208 (1970), p. 582

18）坪田一一, 小林一博, 坂上高志：熱処理， 23 (1981), p. 193

19）大沢真澄：不一越技報， 22 (1966) 2， p. 25 